\title{
THERMALLY-INDUCED GALLIUM REMOVAL FROM PLUTONIUM DIOXIDE FOR MOX FUEL PRODUCTION
}

David Kolman

Los Alamos National Lab.

Mail Stop E510

Los Alamos, NM 87545

(505) 665-6773
Manuel Griego

Los Alamos National Lab.

Mail Stop E511

Los Alamos, NM 87545

(505) $667-2572$
Chris James

Los Alamos National Lab.

Mail Stop E510

Los Alamos, NM 87545

(505) 665-9263
Darryl Butt

Ceramatec, Inc.

2425 South 900 West

Salt Lake City, UT 84119

(801) 956-1022

\section{ABSTRACT}

A process for the separation of gallium oxide from plutonium dioxide using a "dry" process has been developed. The process uses a reducing gas to generate a volatile gallium specie which is collected downstream. The effects of temperature, duration, flow rate, and sample size have been examined. Results indicate that temperature plays a strong role in the efficacy of gallium removal. Other variables have a much smaller effect on gallium removal efficiency. Gallium removal to approximately $1 \mathrm{ppm}$ (atomic) has been observed. Gallium removal to sub-ppm levels appears feasible based on resultsto-date.

\section{INTRODUCTION}

In January 1997, the Secretary of Energy signed a Record of Decision finalizing a dualtrack strategy to irreversibly dispose of the Nation's surplus plutonium. The strategy allows for immobilizing plutonium in inert forms or burning plutonium as mixed oxide (MOX) fuel in existing reactors. There is one potential drawback to using weapons grade plutonium as feed for MOX fuel - weapons grade plutonium contains approximately $1 \%$ gallium. Gallium is known to degrade the properties of many metallic materials via corrosion, embrittlement, or intermetallic compound formation. Thus, there is significant concern that gallium present in MOX fuel will compromise zirconium-based fuel cladding. Removal of gallium from MOX fuel is therefore imperative.

The aim of this work is to develop a "dry" process to reduce the $\mathrm{Ga}$ concentration of weapons-derived $\mathrm{PuO}_{2}$ that is integrable into the pit disassembly and conversion process. A dry

method for Ga removal is desirable for a variety of reasons including waste reduction and relative ease of facility licensing. A dry method for removing $\mathrm{Ga}$ from $\mathrm{PuO}_{2}$ was thought to be possible, based upon initial calculations. It was theorized that a reducing gas could be passed over the powder thereby reducing the solid $\mathrm{Ga}_{2} \mathrm{O}_{3}$ to $\mathrm{Ga}_{2} \mathrm{O}$ gas:

$$
\mathrm{Ga}_{2} \mathrm{O}_{3(\mathrm{~s})}+2 \mathrm{H}_{2(\mathrm{~g})} \rightarrow \mathrm{Ga}_{2} \mathrm{O}_{(\mathrm{g})}+2 \mathrm{H}_{2} \mathrm{O}_{(\mathrm{g})}
$$

Initial tests incorporating $\mathrm{CeO}_{2}$ surrogates and $\mathrm{Ar}$ - $\mathrm{H}_{2}$ gas confirmed that such a process was viable.

\section{EXPERIMENTAL DETAILS}

\section{A. Material Characteristics}

The process development tests incorporate weapons-derived $\mathrm{PuO}_{2}$. This material was produced from $\mathrm{Pu}$ metal using a three-step process (hydride - nitride - oxide). Analysis of the powder (Figure 1) indicated a bimodal particle size distribution with a significant

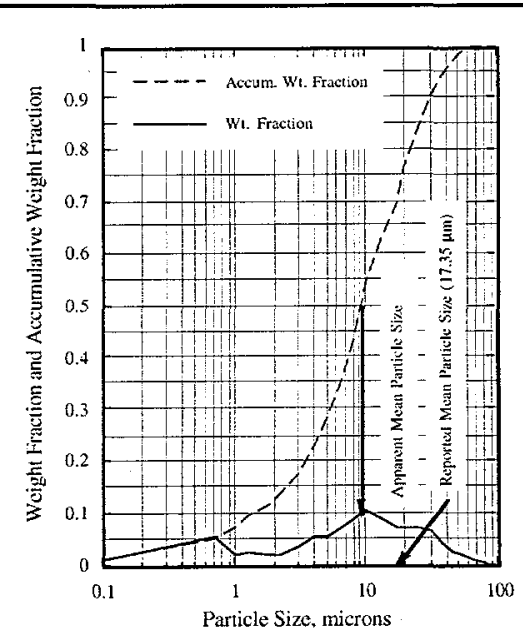

Figure 1 - Particle size distribution and micrograph of three-step $\mathrm{PuO}_{2}$ powder used in this study.

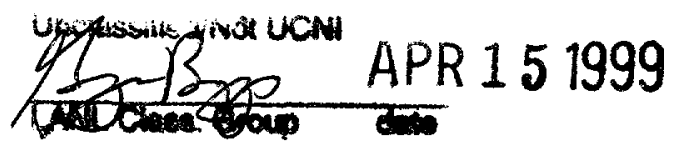




\section{DISCLAIMER}

This report was prepared as an account of work sponsored by an agency of the United States Government. Neither the United States Government nor any agency thereof, nor any of their employees, make any warranty, express or implied, or assumes any legal liability or responsibility for the accuracy, completeness, or usefulness of any information, apparatus, product, or process disclosed, or represents that its use would not infringe privately owned rights. Reference herein to any specific commercial product, process, or service by trade name, trademark, manufacturer, or otherwise does not necessarily constitute or imply its endorsement, recommendation, or favoring by the United States Government or any agency thereof. The views and opinions of authors expressed herein do not necessarily state or reflect those of the United States Government or any agency thereof. 


\section{DISCLAIMER}

Portions of this document may be illegible in electronic image products. Images are produced from the best available original document. 
- fraction of the powder comprising sub-micron particles. This powder was found to have a surface area of $6.4 \mathrm{~m}^{2} / \mathrm{g}\left(+/-0.3 \mathrm{~m}^{2} / \mathrm{g}\right)$. Chemical analysis of this powder (using inductively coupled plasma - mass spectroscopy) indicated a Ga concentration of $0.87 \mathrm{wt} \%(8700 \mu \mathrm{g} / \mathrm{g}(\mathrm{ppm}))$ or 1.1 atomic\%.

\section{B. Test Procedure}

Thermally-induced gallium removal (TIGR) tests comprised the exposure of $\mathrm{PuO}_{2}$ to $\mathrm{Ar}-6 \%$ $\mathrm{H}_{2}$ gas $\left(\mathrm{O}_{2}<8\right.$ ppm, $\mathrm{H}_{2} \mathrm{O}<0.7$ ppm $) . \quad \mathrm{PuO}_{2}$ samples (typically $0.3 \mathrm{~g}, 0.9 \mathrm{~g}$, and $2.5 \mathrm{~g}$ ) were weighed, placed in nonreactive alumina boats, and then reweighed, noting the gross weight of each boat. These small boats were then placed in a large alumina boat to facilitate handling. The large boat was inserted into the hot zone of a tube furnace (see Figure 2). The temperature was ramped at a rate of $20^{\circ} \mathrm{C} / \mathrm{min}$. until the temperature of interest was reached. The samples were held at temperature for a fixed period of time. At the end of this period, the furnace was turned off and the samples were allowed to furnace cool. Following cooling to nearly room temperature $\left(<50^{\circ} \mathrm{C}\right)$, the samples were removed from the furnace, the gas flow was stopped, and the gross weight of the boats recorded. Note that a sample exposed to a higher temperature for the same duration of time as one exposed to lower temperature is exposed to elevated temperature for a longer period of time due to the increased ramp-up and ramp-down time. Temperature, time at temperature, sample mass, and gas flow velocity were varied in an effort to determine the rate limiting step and thus optimize Ga removal.

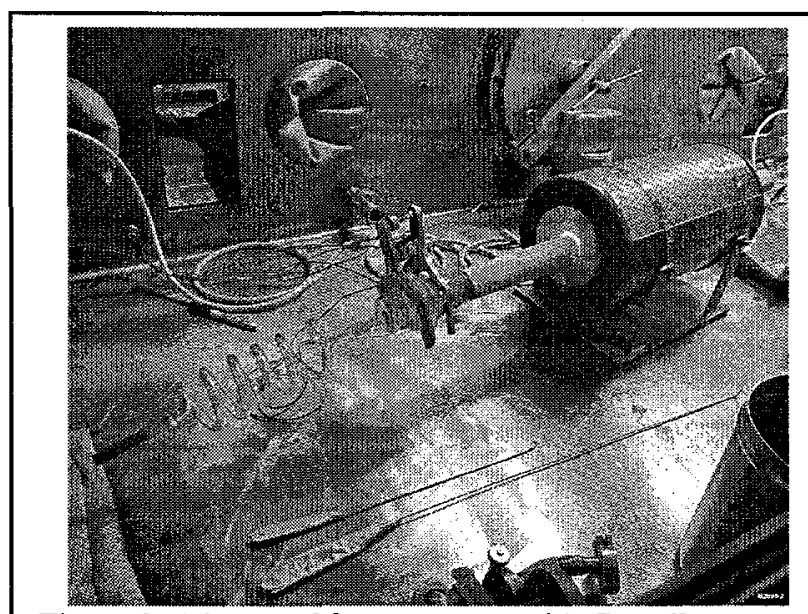

Figure 2 - Picture of furnace setup with Ga collector.

\section{Analysis Techniques}

The extent of Ga removal is best determined by chemical analysis following sample exposure. However, weight loss measurements also can be used to infer Ga removal. This technique is used to yield inside into the reduction of the $\mathrm{PuO}_{2}$. Figure 3 shows that weight loss measurements correlate well with the Ga loss. Thus, weight loss may be used as a predictor of Ga loss. Note that weight losses of greater than $2 \%$ are observed even though $\mathrm{Ga}_{2} \mathrm{O}_{3}$ only comprises 1.2 wt\% of the starting material. This indicates that significant reduction of the $\mathrm{PuO}_{2}$ occurs concurrently with $\mathrm{Ga}_{2} \mathrm{O}_{3}$ reduction / $\mathrm{Ga}_{2} \mathrm{O}$ evolution.

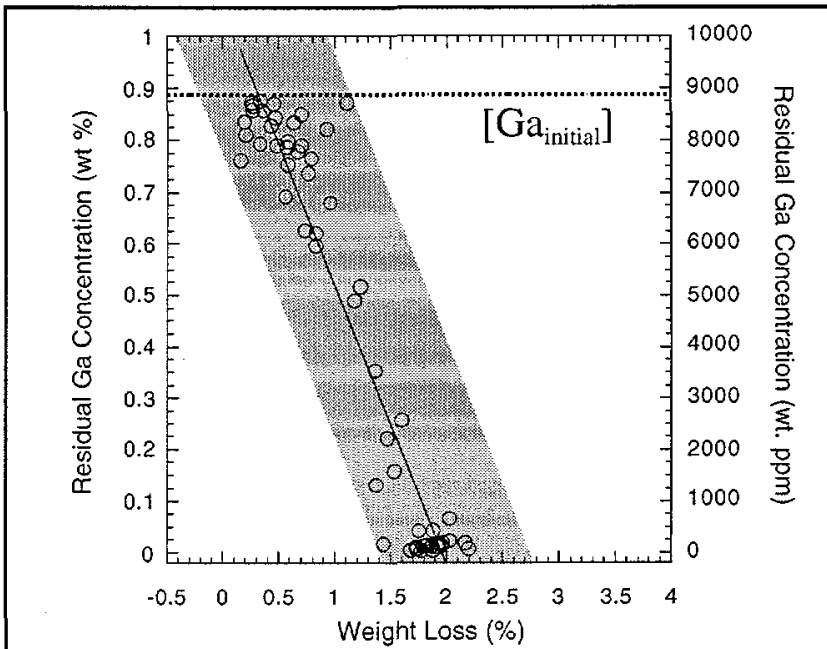

Figure 3 - Correlation of weight loss to remaining gallium concentration following exposure. Data are from tests incorporating various sample masses, exposure temperatures, durations, and gas flow rates.

\section{Reproducibility}

Weight loss measurements yielded superior reproducibility as compared to Ga concentration analyses. Weight loss measurements on four replicate tests $\left(1200^{\circ} \mathrm{C}, 4 \mathrm{~h}, 1.5 \mathrm{~cm} / \mathrm{s}\right.$ gas flow velocity) had standard deviations of $7.0 \%, 12 \%$, and $7.6 \%$ for $0.3 \mathrm{~g}, 0.9 \mathrm{~g}$, and $2.5 \mathrm{~g}$ samples respectively. $\mathrm{Ga}$ measurements were less reproducible. Three replicate tests $\left(1200^{\circ} \mathrm{C}, 4 \mathrm{~h}\right.$, $1.5 \mathrm{~cm} / \mathrm{s}$ gas flow velocity) yielded standard deviations of $29 \%, 8.9 \%$, and $4.2 \%$ for $0.3 \mathrm{~g}, 0.9$ $\mathrm{g}$, and $2.5 \mathrm{~g}$ samples respectively.

\section{RESULTS}

A. Effect of Temperature
RECEIVED DEC 132000 


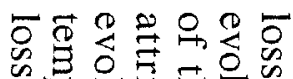

फ.

$\stackrel{2}{*} 0$ \&

.

क

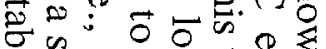

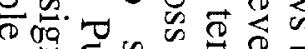

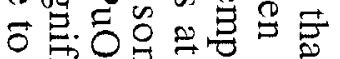

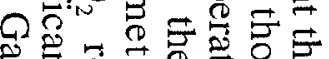

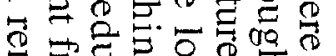

उ

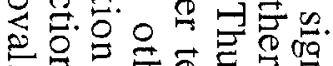

0 ब

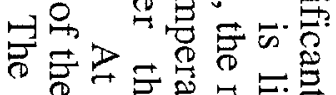

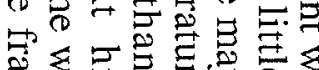

家.

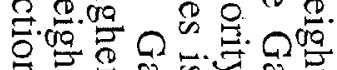
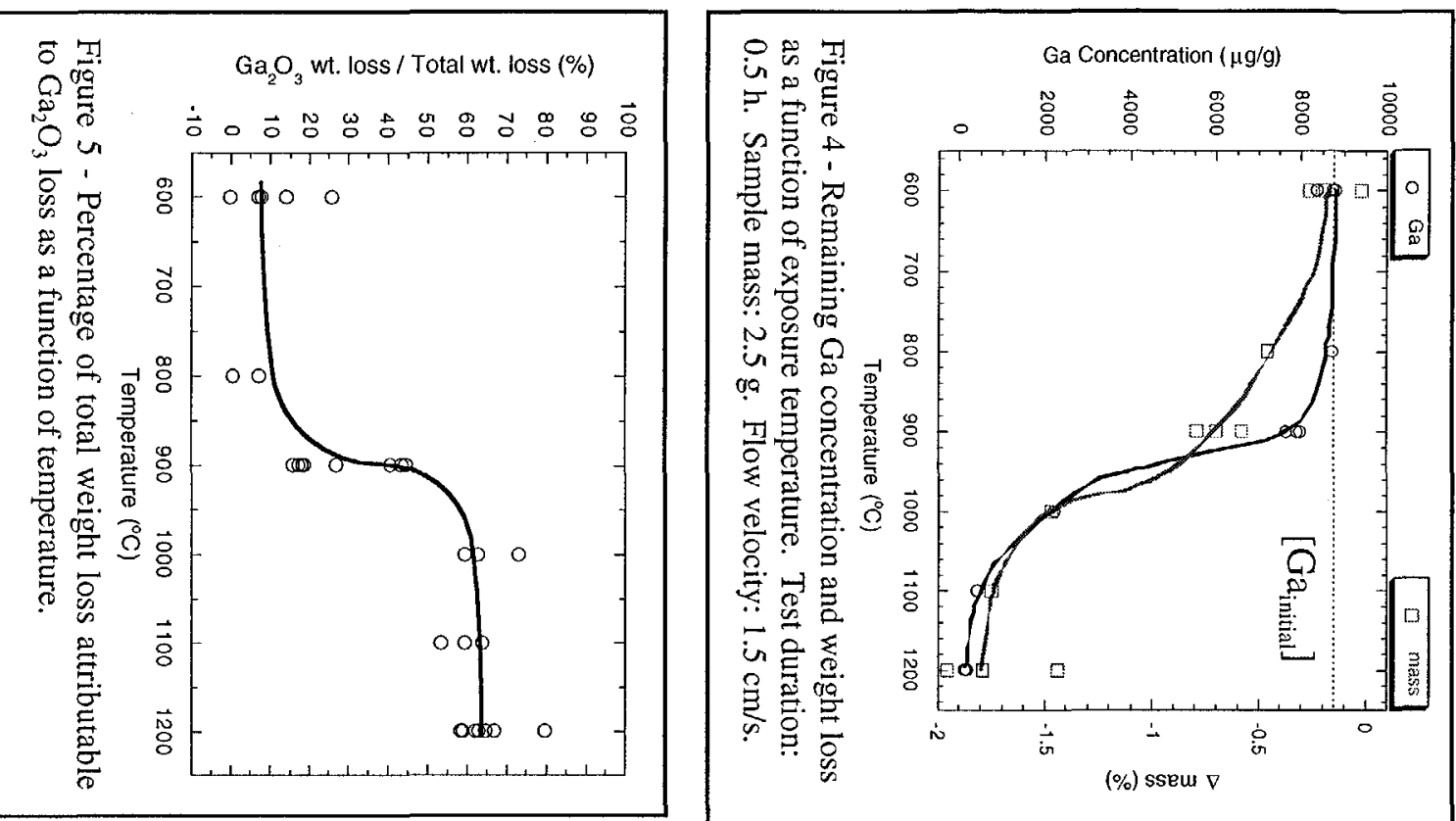

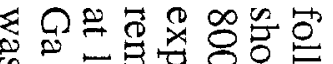

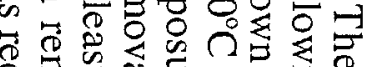

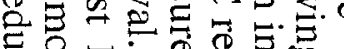

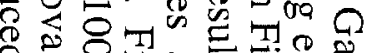
이용 $\cong$

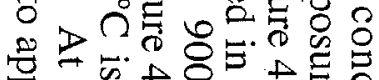

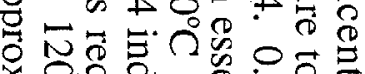
x. 응둥

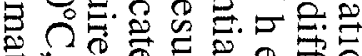

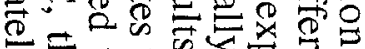
《穴司

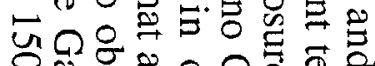

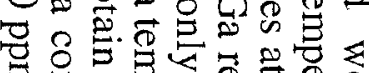

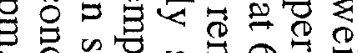

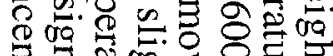

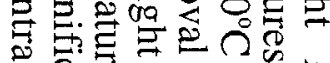

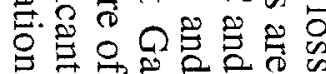

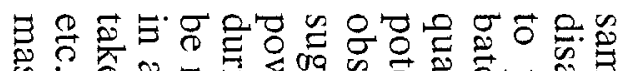

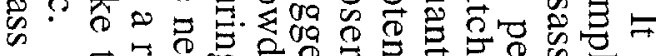

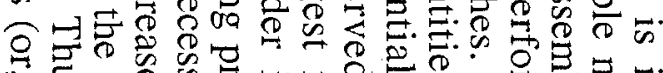

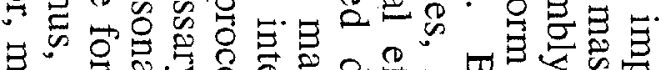

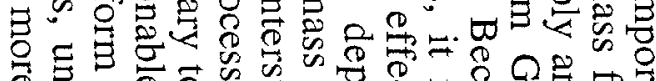
त

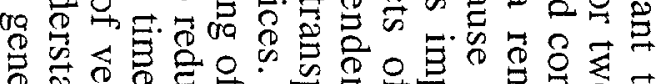

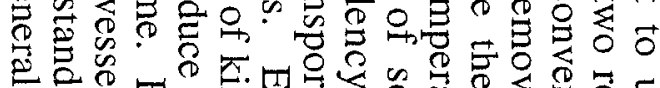

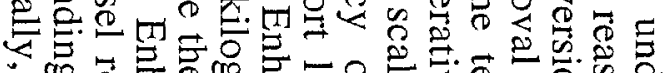

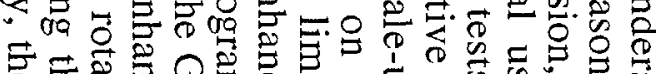
के 苍.

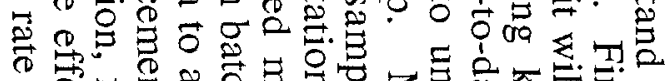

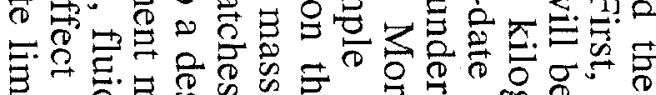

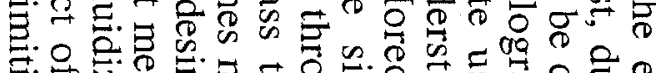

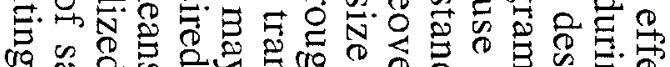

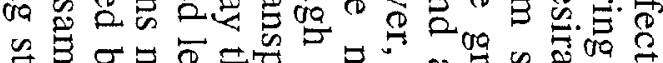

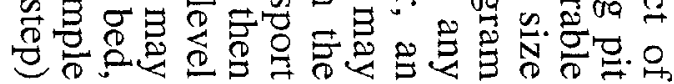
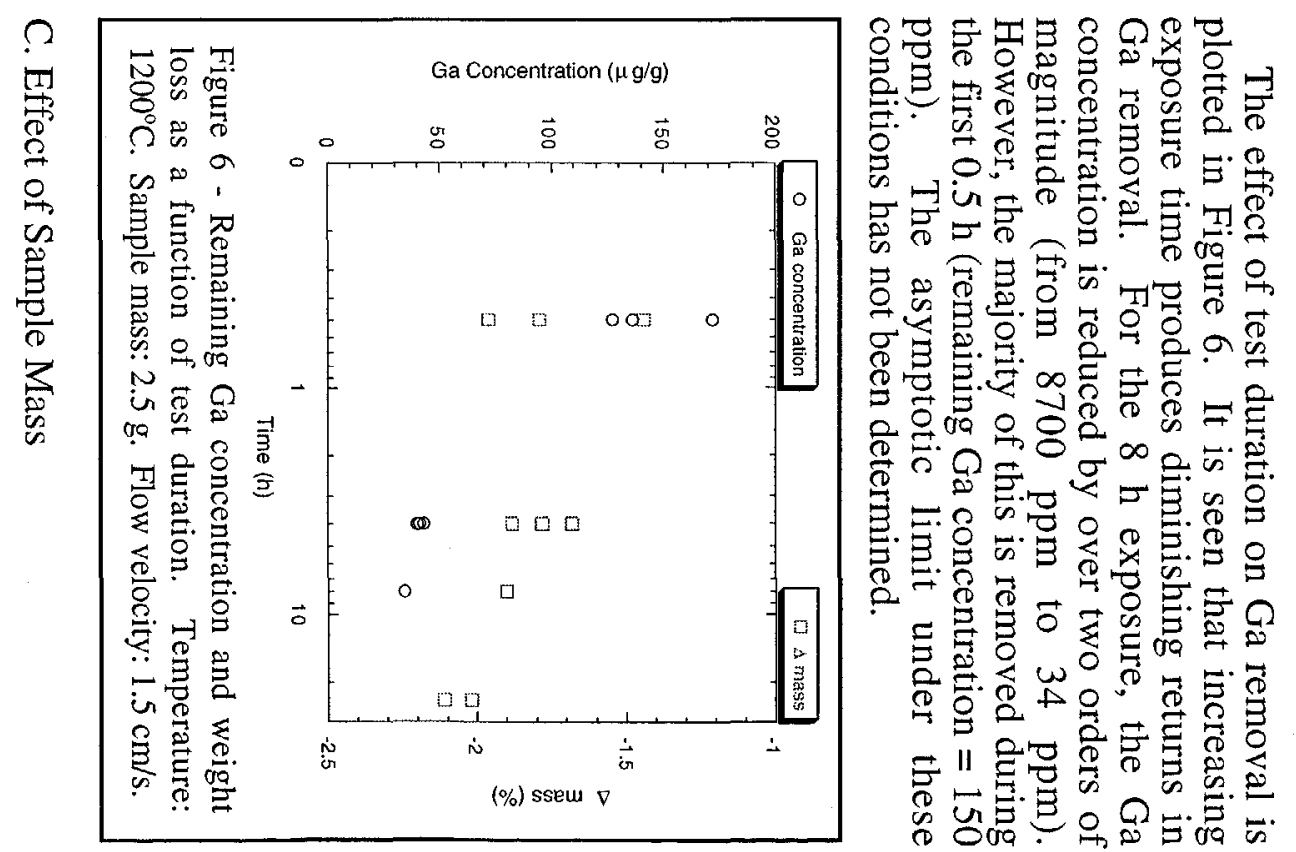

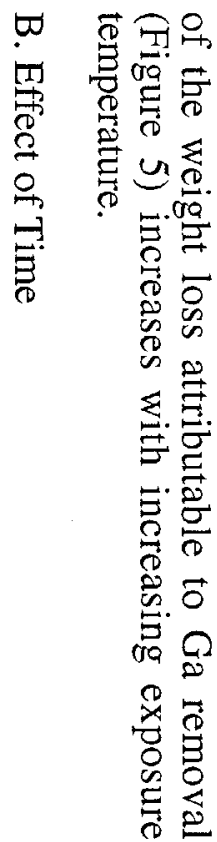


- is necessary in order to design a $\mathrm{Ga}$ removal system.

The effect of sample mass on Ga removal is unclear. Weight loss measurements suggest that increasing sample mass decreases percent weight loss with a confidence of greater than $99 \%$ based on linear regression of the $0.3,0.9$, and $2.5 \mathrm{~g}$ data. However, one test using $25 \mathrm{~g}$ of $\mathrm{PuO}_{2}$ yielded a weight loss similar to the smaller samples (Figure 7). Further, Ga concentration measurements suggest that sample mass has no statistically significant effect on $\mathrm{Ga}$ removal. In summary, the effect of sample size cannot be determined at this time.

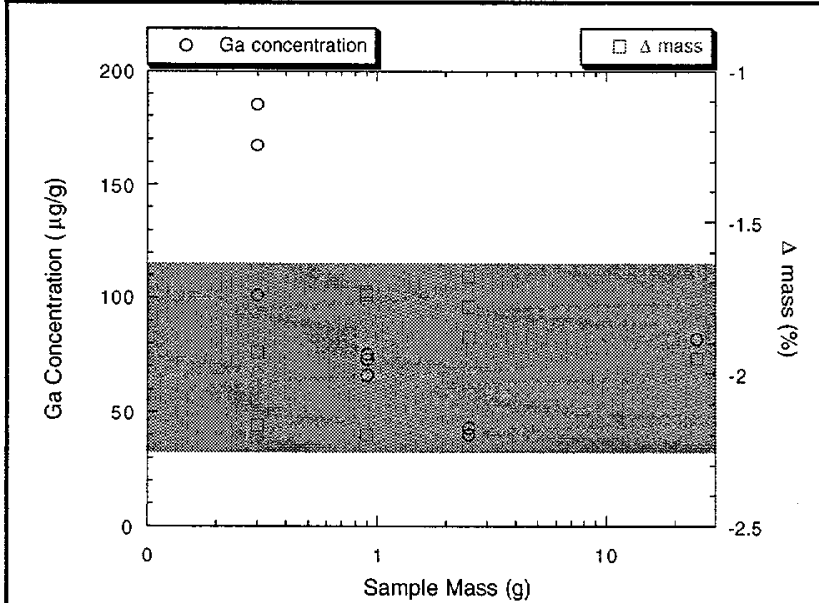

Figure 7 - Remaining Ga concentration and weight loss as a function of sample size. Temperature: $1200^{\circ} \mathrm{C}$.

Test Duration: 4 h. Flow velocity: $1.5 \mathrm{~cm} / \mathrm{s}$.

\section{Effect of Flow Rate}

As with sample size, understanding the effect of flow rate is critical for the determination of the rate limiting step. Analogous to the effect of sample mass, the effect of gas flow rate cannot be unambiguously determined at this time. Initial experiments involved $\mathrm{Ga}$ removal using gas flow rates of $1.5 \mathrm{~cm} / \mathrm{s}$ and $3.0 \mathrm{~cm} / \mathrm{s}$. Weight loss results from tests incorporating identical temperature, time, and sample mass but different flow rate are compared in Figure 8 . There is no apparent difference in weight loss when the flow rate is doubled. That is, for every test condition where mass loss is larger for the faster flow rate, there is a different test where mass loss is larger for the slower flow rate. The same is observed when comparing Ga concentration data. Linear regression of the weight loss and $\mathrm{Ga}$ concentration data confirms this observation.
Thus Ga evolution does not appear to be limited by mass transport of $\mathrm{Ga}_{2} \mathrm{O}_{3}$ away from the boat to its deposition point downstream.

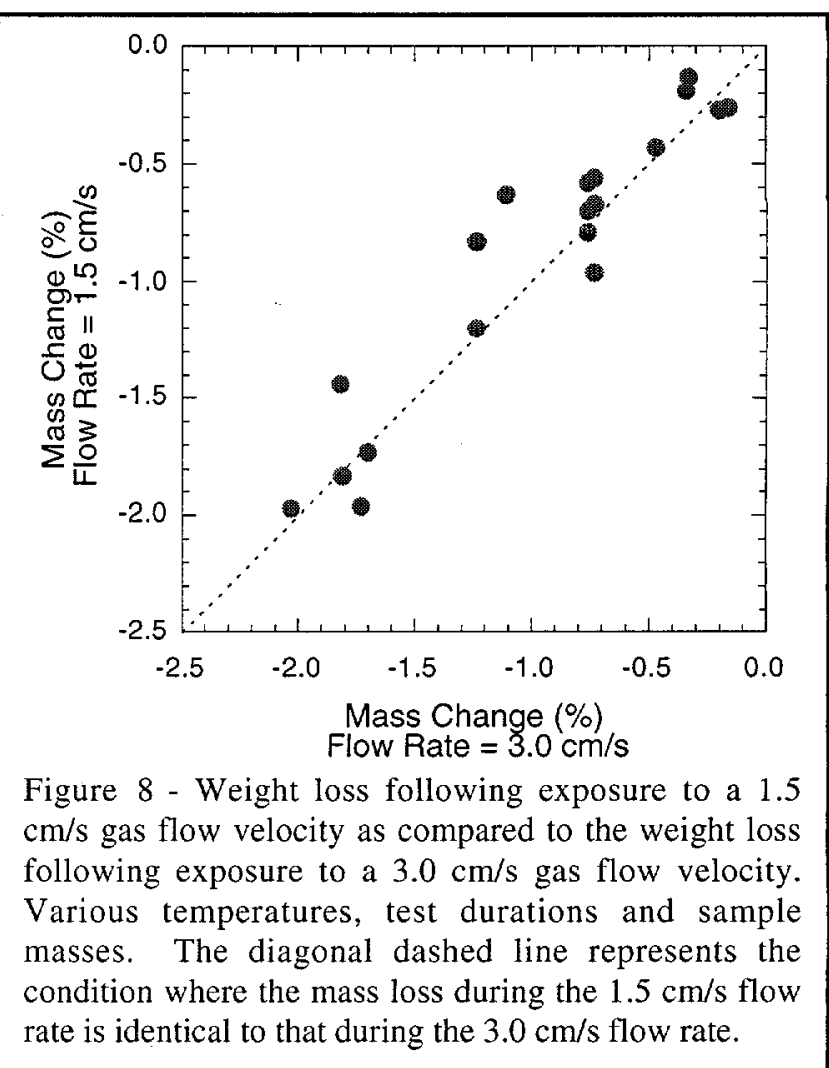

Additional tests were run using much higher flow rates $-13 \mathrm{~cm} / \mathrm{s}$ and $26 \mathrm{~cm} / \mathrm{s}$. Although it appeared that these much higher flow rates may enhance $\mathrm{Ga}$ removal, the effect of flow rate cannot be unambiguously concluded at this time due to significant scatter in the data.

The effect of flow rate on pure $\mathrm{Ga}_{2} \mathrm{O}_{3}$ has been determined (Figure 9). For pure $\mathrm{Ga}_{2} \mathrm{O}_{3}$, doubling the flow rate from $1.5 \mathrm{~cm} / \mathrm{s}$ to $3.0 \mathrm{~cm} / \mathrm{s}$ increases the rate of $\mathrm{Ga}$ evolution. This indicates that $\mathrm{Ga}$ evolution is not reaction rate limited but rather is limited by mass transport. Moreover, calculations indicate that in the event of gas mass transport limitation, $\mathrm{Ga}_{2} \mathrm{O}$ will be the limiting specie, as opposed to $\mathrm{H}_{2}$ or $\mathrm{H}_{2} \mathrm{O}$. Given that $\mathrm{Ga}_{2} \mathrm{O}$ evolution is not reaction rate limited for pure $\mathrm{Ga}_{2} \mathrm{O}_{3}$, evolution will not be reaction rate limited for $\mathrm{PuO}_{2}$. Since $\mathrm{Ga}$ evolution does not appear to be either kinetically limited or mass transport limited by transport away from the boat, there are only two other potential rate limiting steps - mass transport within the $\mathrm{PuO}_{2}$ particles themselves, or mass transport within the interstices between the powder particles. 


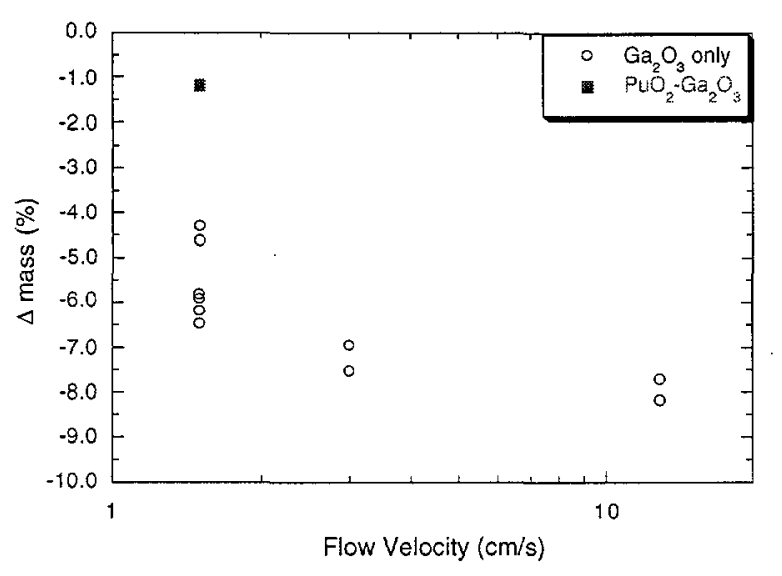

Figure 9 - Plot of mass change as a function of flow velocity for $2.5 \mathrm{~g}$ samples at $900^{\circ} \mathrm{C}$ for $4 \mathrm{~h}$. Data for pure $\mathrm{Ga}_{2} \mathrm{O}_{3}$ and the three-step $\mathrm{PuO}_{2}$ powder are shown.

\section{E. Acceptability of $\mathrm{Ga}$ Concentration}

Although the process for $\mathrm{Ga}$ removal has not been optimized (higher temperatures have yet to be examined), it is of interest to compare the remaining Ga concentration following TIGR to particular $\mathrm{Ga}$ levels that may correlate to particular levels of cladding damage. Figure 1 shows a comparison of remaining $\mathrm{Ga}$ concentration as a function of temperature (data points) to four particular levels. The highest level, level A, appears to be unacceptable based on examination of $\mathrm{Zr}$ clad material microstructure following Ga implantation. Level B appears to be an acceptable concentration based on embrittlement testing. Level $\mathrm{C}$ appears to be an acceptable concentration based on examination of $\mathrm{Zr}$ clad material microstructure following $\mathrm{Ga}$ implantation. Level $\mathrm{D}$ is known to be an acceptable concentration based on levels that are observed in existing MOX fuel as a result of fission. The lowest concentration that we have obtained, $34 \mathrm{ppm}$ in $\mathrm{PuO}_{2}$, was observed following an $8 \mathrm{~h}$ exposure at $1200^{\circ} \mathrm{C} .34 \mathrm{ppm}$ approximately corresponds to $2 \mathrm{ppm}$ in MOX fuel assuming that the MOX fuel is composed of $95 \% \mathrm{UO}_{2}$ and $5 \% \mathrm{PuO}_{2}$. Although the research that determined the suitability of levels A - C is not definitive, it appears at this time that the $\mathrm{Ga}$ removal may be sufficient to avoid clad failure. However, given that the exact concentration to cause clad failure is not known (and may never be known), it is prudent to optimize Ga removal to obtain levels that are as low as reasonably achievable. Higher temperatures $\left(>1200^{\circ} \mathrm{C}\right)$ should readily produce sub-ppm Ga concentrations in the fuel.

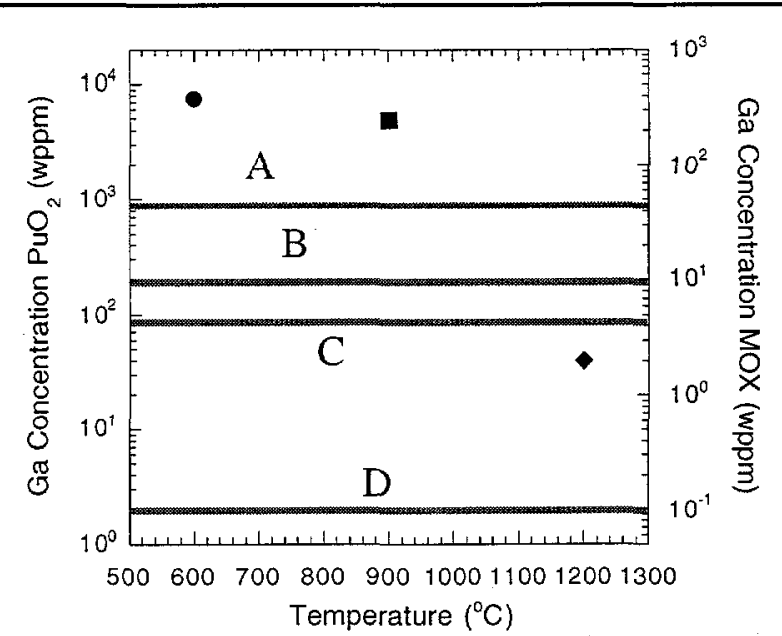

Figure 10 - Comparison of $\mathrm{Ga}$ concentrations following $\mathrm{Ga}$ removal to levels which have known effects on fuel cladding. The values on the right axis are $1 / 20$ of those on the left, i.e., this axis assumes that the MOX fuel is $95 \% \mathrm{UO}_{2} / 5 \% \mathrm{PuO}_{2}$. Level A: Apparently unacceptable - "significant microstructural damage" (R.R. Hart et al., "Gallium Interactions with Ga Zircaloy Cladding", Report \#: ANRCP-1998-5). B: Apparently acceptable - "It does not appear that 10 ppm will have any measurable effect..." (D.F. Wilson et al., "Interactions of Zircaloy Cladding with $\mathrm{Ga}$ : 1998 Midyear Status", Report \#: ORNL/TM-13625). C: Apparently acceptable - "no apparent microstructural damage" (R.R. Hart et al., "Gallium Interactions with Ga Zircaloy Cladding", Report \#: ANRCP-1998-5). D: Acceptable - levels in existing MOX fuel as a fission product. 